\title{
APC Membrane Recruitment Protein 1
}

National Cancer Institute

\section{Source}

National Cancer Institute. APC Membrane Recruitment Protein 1. NCI Thesaurus. Code C68721.

APC membrane recruitment protein $1(1135 \mathrm{aa}, \sim 124 \mathrm{kDa})$ is encoded by the human AMER1 gene. This protein plays a role in both Wnt signaling and phosphatidylinositol-4,5bisphosphate localization. 